This is the version of the article accepted for publication in Third World Quarterly published by Taylor \& Francis https://doi.org/10.1080/01436597.2020.1723076

Accepted version downloaded from SOAS Research Online: $\underline{\text { http://eprints.soas.ac.uk/32217 }}$

Forthcoming, Third World Quarterly

Towards a Conception of the Systematic Impact of China on Late Development

Dic Lo

SOAS University of London

diclo@soas.ac.uk

January 2020

This work was support by ESRC/DFID Growth Programme under grant number ES/M004228/1

(Project Title: „Assessing the Employment Impact of Chinese Firms in Sub Saharan Africa ${ }^{\circ)}$, which is gratefully acknowledged. The author wishes to thank Carlos Oya, Sam Kee Cheng, Christina Wolf, and three anonymous referees of this journal for their helpful comments. 


\title{
Towards a Conception of the Systematic Impact of China on Late Development
}

\author{
January 2020
}

\begin{abstract}
The tremendous expansion of the Chinese economy since the turn of the century, especially in terms of its external dynamics, is of world-scale significance. It seems to justify the quest for appropriate conceptions of China ees systematic impact on late development worldwide. A large number of scholarly studies have coalesced to analyse two crucial aspects of the impact, namely: impact on the performance of industrialization and the condition of labour in the developing world. This paper seeks to critically appraise and reinterpret the existing studies. The appraisal is not so much a critique but rather an attempt to appropriately position the studies in the systematic context. It is submitted that the existing studies ${ }^{\text {ee }}$ focus on market competition, as the main form through which Chinaes impact manifests, needs to be complemented and underpinned by the more fundamental consideration on productive investment. In the direction of constructing a systematic conception, it is further submitted that the China impact can potentially serve as a countervailing force against the prevailing dynamics of the world economy under neoliberal globalization - i.e., the rising predominance of speculative finance that tends to crowd out productive investment, thereby hampering industrialization and worsening labour condition in the developing world.
\end{abstract}

Keywords: China, late development, systematic impact, productive investment 


\section{Introduction}

The tremendous expansion of the Chinese economy since the turn of the century is of world-scale significance. Between 2000 and 2018, China accounted for almost a quarter of the increase in world economic output, and almost a half of the increase in all developing (i.e., low- and middle-income) economies. In the meantime, China accounted for 35\% of the increase in industrial value-added of the world and 56\% in all developing economies. From 2000 to 2017, China ,raised ${ }^{\text {ee }}$, in the accounting sense, the average annual growth of the real wage rates of the world from $1.3 \%$ to $2.3 \%$. Regarding international economic activities, by the 2010s, China became the biggest merchandise-trading economy in the world as well as a major supplier and recipient of international investment. It has also initiated a range of policy programmes, most famously the Belt-and-Road Initiative, aimed at reshaping the economic landscapes of the world. ${ }^{1}$

These developments have given rise to widespread concerns over the nature of the Chinese economy and its interaction with the rest of the world. Given the vastness of the scales, they seem to justify the quest for appropriate conceptions of China ees systematic impact on world development. By systematic impact it refers to the space for development that has been created and acquired by China, vis-à-vis the space in the world as a whole. In the context of global economic stagnation, the immediate concern over development space can be pinned down as the sharing of the world total of macroeconomic demand (and with it the scale of economic activities, employment, etc.). Demand comes from income, and it is China"s role in the creation and acquisition of world income that defines its systematic impact on world development. ${ }^{2}$

Is China a boon, or a curse, for the development of the Global South? Scholarly studies have provided essential building blocks, while seemingly fall short of constructing a systematic conception. They tend to approach the China impact as per the experience of yet another East Asian successful industrializing economy, following the footsteps of Japan, South Korea, and the like. A large number of the studies have coalesced to analyse two crucial aspects of the impact, regarding the progress in 
industrialization and the condition of labour in the developing world. The thesis of „China reinforcing Southern de-industrialization ${ }^{\text {ee }}$ dwells on verifying whether Chinese manufactures exports have been displacing exports from other developing countries in the world market, and/or whether Chinaes imports of primary commodities have been inducing the export countries to specialize in the primary sector. The thesis of „China under-cutting Southern labour ${ }^{\text {ee }}$ dwells on verifying whether Chinese manufactures exports have been driving other developing countries to rely on „cheap labour ${ }^{\text {ee }}$ for the survival of their industries, and/or whether China "s investment in other developing countries has been mainly pursuing ,cheap labour".

This paper seeks to critically appraise and reinterpret the existing studies. The appraisal is not so much a critique, in the sense that it is not purported to explicitly and formally test the theses (and hence it would not question the validity of the associated empirical findings). It is rather an attempt to appropriately position the studies in the systematic context. Conceptually, in the face of competitive pressure from Chinese exports (Chinese labour), whether or not displacing (under-cutting) will occur in a particular developing economy hinges on productivity. Productivity improvement depends on investment. Hence, the crucial question for judging the systematic impact is whether China tends to undermine, or enhance, the capacity of productive investment in the developing world. The consideration on productive investment should be seen as more fundamental than, or at least complementary to, that of market competition.

Placing productive investment at the centre of the investigation into the systematic impact does have its empirical foundation. The Chinese economy is well-known of its production-orientation, with its rate of productive investment far exceeding the rest of the world. It is also imperative for China to promote productive investment in the broader world. As will be explained below in the paper, neoliberal globalization has been associated with the rising predominance of speculative finance that tends to crowd out productive investment (thereby hampering industrialization and worsening labour condition in the developing world). China has been resisting such systemic dynamics of the world economy. The resistance has had to be undertaken in the broader scope from the early $2010 \mathrm{~s}$, amid the 
rapid deepening of the integration of the Chinese economy into the world market. It appears that China constitutes a significant countervailing, instead of preserving, force vis-à-vis the prevailing systemic dynamics of the neoliberal world. It is, ultimately, in this sense, that the quest for systematic conceptions of the China impact is justified. ${ }^{3}$

The paper is divided into five sections, of which this introduction is the first. Section two outlines the main attributes of China"s international economic activities, which are the direct mechanisms mediating the interaction between China and world development. Section three critically reviews and reinterprets, in relation to the indicated attributes and drawing on a range of relevant studies, the theses of „China reinforcing Southern de-industrialization ” and „China under-cutting Southern laboure. Section four turns to delineate the systemic dynamics of the Chinese economy, visà-vis neoliberal globalization. This delineation serves to both substantiate the argument that China is inclined to promote productive investment in the broader world, and to address the counter-factual view that productive investment in the developing world could have been curtailed rather than enhanced in the absence of China. Section five concludes the paper.

\section{Attributes of China's International Economic Activities}

The interaction between China and the broader world economy is mediated by its international economic activities. Merchandise exports and outward direct investment have been the main immediate mechanisms through which China impacts world development. Between 2000 and 2018, China ${ }^{e} \mathrm{~s}$ world share of merchandise trade increased from $4 \%$ to $12 \%$, making it the biggest trading economy in the world. In 2018, Chinaes s world share of merchandise trade exceeded that of the United States (11\%) and Japan (4\%). The contrast in exports is even starker. In the same year, China ${ }^{\text {ees }}$ world share of merchandise export was 13\%, which exceeded the sum total of the United States (8\%) and Japan (4\%). From these measures, it seems as if the world" s second biggest economy is more „open“, or „outward lookingee, than the biggest and third biggest economy. 
Three characteristics of China"es international trade are of note.

- First, trade balance: China has always run trade surpluses since the early 1990s and of hefty magnitudes from the mid-2000s onward, as is shown in Figure 1 by the gap between the two curves that represent total exports and imports. This is true even in the period of continuous and rapid appreciation of its currency vis-à-vis its major trading partners, and of continuous and rapid rise of the wage rates. Between January 2000 and January 2017, China ${ }^{e e}$ s nominal effective exchange rate appreciated by $32 \%$ while the real (consumer price index-based) effective exchange rate appreciated by $34 \% .{ }^{4}$ In the same period, the real urban wage rate and the real wage rate for migrant workers on average increased by $10.7 \%$ and $9.7 \%$, respectively, per annum (see Figure 6 below).

- Second, growth: both merchandise exports and imports have registered rapid growth for decades. As can be computed from the data in Table 1, the average rate of nominal annual growth of exports and imports was $14 \%$ and $13 \%$, respectively, in the period 1980-2000. The same growth rates basically remained in the subsequent period of 2000-2018. Consequently, trade surpluses amounted to US dollar 351 billion in 2018, equivalent to $2.6 \%$ of GDP in that year.

- Third, composition of exports and imports: the share of manufactures in total exports increased from $50 \%$ in 1980 to $95 \%$ in 2018 . In contrast, the share of manufactures in total imports increased much more modestly, from $65 \%$ to $67 \%$. Exports under the category „machinery and transport equipment" have registered the fastest expansion. Their shares in total exports increased from 5\% in 1980 to $49 \%$ in 2018 .

[Figure 1], [Table 1]

China ${ }^{\text {ee }}$ trade with the rest of the developing world has grown especially fast. Between 2000 and 2017, the average nominal rate of growth in its total merchandise trade with developing economies registered $18 \%$ per annum, compared to that with developed economies (,high-income economies ${ }^{e c}$ ) of 
$12 \%$. Moreover, whilst China has been running surpluses with developed economies, its trade with developing economies has been in most years in sizeable deficits. During this period, China also experienced continuous worsening of its international terms of trade, whereas the opposite was true for the developing world as a whole. Between 1998 and 2018, China"s net barter terms of trade decreased by a magnitude of $24 \%$. This stood in contrast to the modest decrease (3\%) for developed economies, and the massive increase (53\%) for all developing economies excluding China (Figure 2).

[Figure 2]

Similar to international trade, since the turn of the century, Chinaees performance in foreign direct investment (FDI) has been spectacular. Between 2000 and 2018, China accounted for 25\% of the increase in the total of FDI flows (inflows plus outflows) in the world, and $51 \%$ in the total of all developing economies. There is a complexity specifically for the data of (mainland) China flows, though: the high proportion of inflows from, and outflows to, the Hong Kong region. In 2018, the inflows from Hong Kong and the outflows to Hong Kong accounted for $67 \%$ of total inflows and $61 \%$ of total outflows, respectively. It is not clear how much of these flows is „round-trippinge in nature, or true FDI using Hong Kong as an intermediate destination. ${ }^{5}$ Provided that the proportion of „round-trippingee flows do not fundamentally alter the picture, China remains as a major supplier and recipient of FDI in the world. And there are observably three important characteristics. ${ }^{6}$

- First, geographical distribution: the lion"s share of China"es outward FDI has flown to the developing world, although investment in developed economies has increased at a faster pace in recent years. In 2018, 71\% of Chinaes outward FDI flows went to developing and transition economies. By the end of that year, of the total stocks of China ${ }^{e e}$ s outward FDI, $88 \%$ were in developing and transition economies. ${ }^{7}$

- Second, sectoral distribution: China ${ }^{e e}$ s outward FDI has concentrated in activities that appear to be trade-related services. These include business services, wholesale and retail sales, 
finance, and information technology services, which combined to account for $67 \%$ of the stock of Chinaees outward FDI by the end of 2018. Nevertheless, there was a degree of variation across different continents. The patterns in Asia and Latin America and Caribbean gear towards trade-related services, while that in Africa is comprises mainly of activities known as „building infrastructure in exchange for resources ${ }^{\text {ee }} 8$

- Third, agents of investment: hitherto, state-owned enterprises (SOEs) have played a more important role than non-SOEs in carrying out the investment. By the end of 2008, of the stock of outward FDI, $70 \%$ was accounted for by SOEs. The share decreased to $48 \%$ by the end of 2018 , while, at the same time, another $27 \%$ was accounted for by mixed-ownership shareholding companies. This change reflects partly the ownership reform of Chinese SOEs. It also reflects partly the division of labour between SOEs and non-SOEs: SOEs, typically of bigger sizes and less profit-oriented, and their activities being associated with state strategies and supports, tend to pave the way for the subsequent entry of non-SOEs.

On the whole, as far as Chinese investment in the rest of the developing world is concerned, serving merchandise trade seems to have been the main consideration. Whether or not, or to what extent, this picture of the sectoral and geographical distribution of China"s outward FDI could be altered by the peculiar role of Hong Kong needs further investigation. Insofar as the picture is not substantially altered, it is observed that the trading in question has been mainly an exchange of manufactures for commodities.

\section{Two Existing Theses on China's Impact on Late Development}

The Theses of 'Reinforcing De-industrialization' and 'Under-cutting Labour' 
Relevant studies on China ${ }^{\text {ee }}$ impact on world development are diverse in terms of the scope of focus, the analytics, the empirical findings, and the concluding judgements. Nevertheless, discernibly, a large number of the studies have coalesced around two theses - namely, the thesis of „China reinforcing Southern de-industrialization" and that of „China under-cutting Southern labour"

Studies pertaining to the first thesis typically ask two questions. First, have Chinese products displaced the manufactures by other developing economies in the markets? Second, have China ${ }^{\text {ee }} \mathrm{s}$ imports of primary commodities induced the export countries to exceedingly specialize in the primary sector ${ }^{9}$ The studies have tended to give affirmative answers to the two questions. These include studies on the displacement effect on the manufacturing sectors in East Asia, Sub Saharan Africa, and Latin America. ${ }^{10}$ Across the world, the displacement effect from Chinese exports is found to be mainly evident in middle-income economies and much less so in low-income and high-income economies. ${ }^{11}$ Additionally, existing studies do find evidence of China trade inducing developing economies that export primary commodities to increasingly specialize in that sector. ${ }^{12}$

Studies pertaining to the thesis of „China under-cutting Southern labour"e typically approach the issue in two fronts. ${ }^{13}$ Concerning investment, case studies do find evidence that Chinese investors have treated employees unfavourably in terms of labour standards and compensations. ${ }^{14}$ Yet, case studies also find that Chinese investors are just as profit-oriented as investors from other countries, and hence their similar pursuit of the lowest possible labour cost. ${ }^{15}$ Further case studies reveal that employment relations within Chinese business establishments in developing countries vary across different circumstances, depending on local political-economic conditions. ${ }^{16}$ To systematically verify the ,under-cuttingee thesis requires ascertaining the effect of China on the broader conditions of labour employment in the developing countries in question. This entails falling back on the issue of displacement effect, together with conjecturing the importance of ,cheap labour" in accounting for the competitiveness of China ${ }^{e e}$ s manufactures exports. Concerned scholars argue that „,cheap labour ${ }^{\text {ee }}$ has indeed been the main factor behind China "es export competitiveness, and, through the pressure of competition, it has forced the rest of the developing world to „cheapen labour. A process of the „race 
to the bottom" in labour standards, where the bottom is allegedly defined by the conditions in China, has thus been at worked on the global scale. ${ }^{17}$ Empirically, it is possible to find evidence that the penetration of Chinese manufactures into the home markets of developing countries has indeed adversely affected the latter"s labour employment. ${ }^{18}$ For this to be a substantiation of the ,undercutting "e thesis, however, the conjecture over ,cheap labour"e in China needs to hold.

\section{Contextualizing the Theses}

The two theses summarised above might well be partial in nature for studying Chinaes systematic impact on world development. Conceptually, focusing on displacement is not necessarily sufficient to capture the full developmental effects arising from the opening up of bilateral trade or integration into multilateral trade. The theses can also be empirically partial, in the sense that they might have missed out some other channels through which China trade and investment impact the developing economies in question. This partial nature of the theses can be seen in the light of a range of studies that employ broader theoretical frameworks for analysing the China impact.

In an exercise that is in the spirit of computable general equilibrium analysis, Adrian Wood and Jörg Mayer find that China ${ }^{e e}$ s manufactures exports, by altering the global pattern of comparative advantage, do have the industry-displacing and primarization-inducing effects for many developing economies, although the magnitudes of the effects are small for the economies in question. ${ }^{19}$ In a different computable general equilibrium analysis of gains from trade arising from Chinaee $\mathrm{s}$ economic expansion, Julian di Giovanni et al. find that economies with comparative advantage similar to China, in labour-intensive production, tend to suffer from China ${ }^{e e}$ trade expansion. They also find that, in a dynamic setting with technological change, these countries benefit from Chinaees trade expansion if China has faster productivity growth in sectors that it does not have comparative advantage. ${ }^{20}$ This way, compared to studies pertaining to the two afore-mentioned theses, both Wood and Mayer and di Giovanni et al., use broader frameworks for analysis. In the meantime, though, the frameworks are 
narrower in a different respect: the appropriateness of comparative advantage (and gains from trade) analysis for capturing the systematic impact of China might need to be ascertained in the first place.

Christina Wolf analyses the China impact within a structuralist framework, which, again, is broader in scope but more specific in theory, compared to the two theses in question. Drawing on Post-Keynesian theories, Wolf highlights the importance - for the industrialization of relevant developing economies - of the easing of the constraints of balance of payments and development finance thanks to the China-induced improvement in international terms of trade. The China-invested infrastructure projects also seem to have contributed, via linkage effects, to domestic market formation that is conducive to industrialization. ${ }^{21}$ As for the direct impact on industrialization, consideration is needed for balancing the negative effect of displacing labour-intensive manufactures and the positive effect of the availability of cheap capital goods from China. The importance of capital goods from China is also emphasized by Daniel Poon, where it is submitted that, compared to capital goods from advanced countries, Chinese goods tend to embody a higher degree of appropriate technology for developing economies. ${ }^{22}$

Dani Rodrik, and Jesus Felipe and Aashish Mehta, approach the systematic China impact on the basis of broader world-scale stylized facts, instead of broader theoretical frameworks. ${ }^{23}$ Central to their studies is the emphasis on the importance, and urgency, of industrialization in the developing world under globalization. Felipe and Mehta report that manufacturinges share in world income and employment has remained stable, but there has been relocation of industry on a gigantic scale to just a few developing economies. Rodrik further highlights the danger of premature de-industrialization for developing economies. It is on this basis that studies pertaining to the two theses on the China impact are justified, and the investigation into displacement effects is important. Even so, these theses need to be contextualized, in relation to industrialization on the world scale. Rodrik also, at various levels, note the importance of the further China effects over and above displacement - such as the dynamic effects identified by di Giovanni et al., and the demand-side effects identified by Wolf. 


\section{The Theses in Relation to the Broader Empirical Picture}

Existing studies pertaining to the theses of „reinforcing de-industrialization ${ }^{\text {ee }}$ and ,under-cutting laboure are mostly case studies of particular regions, countries, or industries. Qualifications and cautions are needed for drawing concluding judgements from their findings on China ses systematic impact, in view of their narrowness in both theoretical frameworks and scopes of empirical investigations.

Outside China, industrialization in the rest of the developing world since the turn of the century is not plainly a record of failure. The world share of manufactures exports from developing economies excluding China actually increased from $12.5 \%$ in 1999 to $15.3 \%$ in 2012 , before falling back to $13.5 \%$ in 2017 (Figure 4). The same pattern is observable regarding the world shares of manufacturing value-added: all developing economies excluding China increased their share from $12.9 \%$ in 1999 to $21.0 \%$ in 2012, before falling back to $19.3 \%$ in 2017 (Figure 5). Displacement effects in the absolute sense of directly suffocating industrialization in the rest of the developing world, though found to be presence in the case studies of various particular economies, do not seem to be true for characterizing the overall picture of the impact of Chinaes ${ }^{\text {es }}$ export expansion.

[Figure 4], [Figure 5]

The increase in the world share of manufactures exports from the rest of the developing world has substantially lagged behind that from China, though. Between 1999 and 2017, Chinaes share increased by 12.9 percentage points, whereas the rest of the developing world increased by just one percentage point. The contrast in the increased world shares of manufacturing value-added is similar: between 1999 and 2017, China had an increase by 21.3 percentage points, while the rest of the developing world increased by 6.9 percentage points. Perhaps, should there be no „China impacte, the rest of the developing world could have gained a much bigger space for pursuing industrialization? 
The performance of China vis-à-vis the rest of the developing world in manufacturing appears to be correlated with differences in productive investment. Between 2000 and 2017, China ${ }^{\text {ees world }}$ share of gross capital formation increased by 20.5 percentage points, while the rest of the developing world increased by 8.4 percentage points. The average ratio of gross capital formation to GDP, for the period 2000-2017, is $43.1 \%$ for China and $24.7 \%$ for all other developing economies combined (Table 2). This correlation raises the question regarding the direction of causation between export and output performance, on the one hand, and productive investment, on the other hand.

[Table 2]

Two theoretical strands, on primarization in developing economies, are of insight for investigating into the nexus of de-industrialization and (lack of) productive investment. The theory of the Dutch Disease, focusing on issues of incentive, posits that the movements of relative prices (particularly the exchange rate) following a commodity boom tend to induce investment to shift away from industrialization. In contrast, the Dependency interpretation of the Prebisch-Singer thesis, on the deterioration of the terms of trade against primary commodities, focuses on capability. It posits that the deterioration tends to result in the outflows of the investible economic surplus of developing economies, thereby undermining their capability to industrialize. These views can be rephrased in the following way. First, industrialization requires investment utilizing available economic surplus. Second, de-industrialization can be caused either by lack of capability or lack of incentive to invest. Third, lack of capability due to surplus outflows is externally caused, while lack of incentive due to the „misuse $e^{\text {ee }}$ of surplus is internally caused. Neoclassical economics need not agree that deindustrialization is a ,misuse $e^{e e}$ of resources, provided that it is in line with the principle of comparative advantage. Dependency theory, meanwhile, contends that the „domestice can just be an outcome dictated by the prevailing dynamics of the world political-economic system.

In view of the major attributes of China ${ }^{e e}$ international economic activities, detailed in the previous section, it is unlikely that there have been systematic surplus transfers - of a scale that 
matches the discrepancy in gross capital formation indicated in Table 2 - from other developing economies to China. Also recall that, alongside the expansion of trading with China since the turn of the century, there has been a trend of improving terms of trade for the rest of the developing world. It is likely that lack of incentive, in the relevant developing economies, has blocked the utilization of incomes from the China-related commodity booms to invest in industrialization.

The contrast in productive investment can also serve as counter-evidence to the thesis of „under-cutting labour"e. Recall the rapidly rising share, in China"es total exports, of machinery and transport equipment, which can be reasonably classified as capital-intensive rather than labourintensive. Recall also the fast expansion of Chinaecs exports, and the persistence of trade surpluses, amid the massive appreciation of the yuan. In addition, note that wage rise was rather rapid precisely during this period of China ${ }^{\text {ee }}$ rapid expansion in international trade and outward investment. Between 2000 and 2018, the average annual growth of real wage rate was $10.4 \%$ for urban registered employees and $9.1 \%$ for migrant workers, both exceeding the $8.8 \%$ of the average annual growth of real per-worker GDP (Figure 6). To achieve the export expansion amid the currency appreciation and wage rise required sufficiently fast growth in labour productivity. And it is conceivable that this fast productivity growth was associated with the fast growth in productive investment.

[Figure 6]

All these said, the ,under-cutting labour" thesis appears to be far less convincing than the alternative thesis that productive investment was the main driving force behind Chinaees productivity growth, industrial upgrading, and, therefore, export competitiveness. Insofar as the rest of developing economies did find themselves compelled to cheapen labour with a view of withstanding competition by Chinese manufactures, this might have been mainly due to their insufficiency in productive investment. Prima facie, this discrepancy between China and the rest of the developing world in productive investment must somehow be ascribable to differences in their respective politicaleconomic conditions. 


\section{China vis-à-vis Globalization: Systemic Dynamics and Systematic Impact}

The thesis of „reinforcing Southern de-industrialization “, and even more so that of „,under-cutting Southern laboure, rests on a particular perception of the prevailing model of economic development in China. This is a model of export-oriented, labour-intensive industrialization mainly based on „cheap laboure. The relationship between such model and the displacement effects on other developing economies is self-explanatory: that China needs to rely on the expansion of labour-intensive manufactures exports for sustaining its economic growth and employment. The relationship with „under-cuttingee is also conceivable: that the competitiveness of China"s manufactures exports is said to have been sustained by „cheap labour"e, i.e., low wage rates, at least relative to productivity.

The claim that Chinese exports have been mainly labour-intensive products, and the perception of ,cheap labour" in China, are not consistent with the empirical evidence presented in Section two. The portrayed „China modele of economic development in general, as will be seen below, is far from accurate. But, irrespective of the accuracy of the claim, perception, and portrait, for the afore-mentioned relationships to hold, the role of China in world development needs to be of systematic significance - not just due to its size but, rather, due to its interaction with the prevailing systemic dynamics of neoliberal globalization. Clarifying such dynamics is thus needed for pinning down the impact of China on late development worldwide, over and above the two theses under review.

\section{A Sketch of the Systemic Dynamics of World Development under Globalization}

The systemic dynamics of wold development can be gauged by characterizing the core policy doctrines of globalization. The doctrines, known as the Washington Consensus, are neoliberal in nature and have been mainly composed of three generations of policies: market and trade 
liberalization, privatization of public assets and services, and financial liberalization especially concerning the de-regulation of cross-border capital flows. These policies combine to make economic resources increasingly financially tradable, and speculative finance becoming increasingly predominant in the economy. Since the early 1990s, a process of financialization has been central to the systemic dynamics of wold development.

Theoretically, financialization, or capital being increasingly oriented to speculative activities, necessarily leads to crowding-out of productive, long-term investment. This crowding-out also tends to worsen income distribution between capital and labour, thereby depressing consumption growth. World development under globalization thus tends to encounter systematic demand deficiency. Moreover, the nature of speculative activities is such that they tend to focus on redistributing profits, not creating profits. Economic crises thus tend to first erupt in the financial sector, in the form of financial volatility or even financial collapse. The logic of financialization, in short, is to make itself intrinsically unsustainable. ${ }^{24}$

In reality, financialization has actually been sustained for a prolonged period, up until the outbreak of systematic crises from 2008. The key to resolving this paradox is the concept of „accumulation by dispossession ${ }^{\text {ee }}$ capital accumulation under neoliberalism is mainly based on the absorption into the world market of productive resources that have been previously outside of it. In its formulation by David Harvey, the concept refers mainly to ,predation, fraud, and thievery various forms of wealth- or profit-seizing speculative financial activities. Harvey also refers the concept to the expansion of the working class, by means of incorporating workers in the developing world into the system. ${ }^{25}$ This second point implies capital chasing ,cheap labour" around the world. A

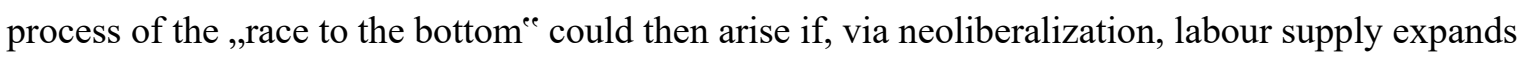
faster than labour demand. The profits so created and extracted could then serve to sustain the process of financialization. 
Harvey in his exposition on ,accumulation by dispossession" seems to emphasize predatory activities while downplaying labour absorption. This treatment does have its reasons. Theoretically, in the context of financialization, capital in general is inclined to pursuing profits via speculation more than production. If possible at all, capital tends to dissociate itself from particular input-output configurations in particular locations. Insofar as production is necessary, avoiding large-scale sunk investment and pushing to the maximum degree of the substitution of labour for capital, are logical of this inclination. Empirically, there is evidence that the political-economic establishments of today ${ }^{\text {ees }}$ world have been in a significant measure dominated by the so-called Wall Street-Treasury-IMF Complex. Predatory activities by speculative finance were quite evident in the series of developmental crises under globalization. ${ }^{26}$

All these said about predatory activities, it can be argued that labour absorption is no less important for ,accumulation by dispossession “. The IMF estimates that, in the period 1980-2005, the number of workers effectively producing for the world market quadrupled, and that increase mostly came from developing economies. ${ }^{27}$ Such a rapid pace of labour absorption has most likely created a situation that can be dubbed ,the Lewis Model on the world scale ${ }^{e e}$ a situation of unlimited supply of labour from the South for employment by capital from the North. This being the case, the ramification for world development could be very problematic. In times of expanding labour absorption, the unequal power between capital and labour entails surplus transfer from the South to the North. This, in turn, implies a tendency to induce the developing economies involved to fall into a „low technology, low wage trap. In times of crises, the relevant developing economies tend to bear the brunt of the systematic shocks arising from demand deficiency. In this context, some developing economies could still benefit from the labour absorption, if they manage to raise their labour productivity fast enough to more than compensate for the surplus outflows. But this must be exception, rather than the norm, in the face of the crowding-out of productive investment and the tendency of the ,race to the bottom

The characterization above, to be sure, is no less theory-specific than the neoclassical general equilibrium analyses and the structuralist demand-side and linkage analyses, which have been 
referenced in Section three for contextualizing the two theses under review. Yet, insofar as the characterization does have elements of truth, its focus on capturing the systemic dynamics of world development can be very useful for investigating into the subject matter of this paper.

\section{The 'China Model' beyond Export-oriented, Labour-intensive Industrialization}

Has China "e s economic expansion been reinforcing, or undermining, the systemic dynamics of world development characterized above? To answer this question requires dissecting the interaction between China and world development, as well as the direction of its domestic economic transformation. It is necessary to verify whether export-oriented, labour-intensive industrialization has been the mainstay of the „China modele of economic development since the turn of the century. Available evidence suggests that it is not.

Consider labour absorption. Incorporating Chinese labour into the world market has been crucial for the formation of ,the Lewis Model on the world scale“. Recall the IMF estimate that the effective labour force of the world market quadrupled between 1980 and 2005. This estimate is constructed by summing over the national data of total labour forces adjusted by their export-to-GDP ratios. Using a simpler, aggregate measure of the same indicator, the number of workers effectively producing for the world market in 2005 is founded to be 2.28 times of that in 1980 , whilst the estimate for all developing countries is 3.79 times and that for China alone is 8.65 times. The world share of the number of Chinese workers producing for the world market increased from $8 \%$ in 1980 to $32 \%$ in $2005 .^{28}$

Along with labour absorption are the drawbacks as suggested by the characterization above of the dynamics of world development. The renowned „Foxconn Model ${ }^{\text {ee }}$, a model of manufacturing sweatshops controlled by transnational capital, has often been cited as representative of the Chinese economy as a whole. It is symptomatic of developmental drawbacks such as low capital-labour ratio, 
high work intensity and low wage rates at the micro level, and under-consumption at the macro level. The result is surplus outflows in times of expansion, and excess capacity in crisis-ridden times. ${ }^{\mathbf{2 9}}$

Is the „Foxconn Modele $^{\text {ee }}$ representative of the Chinese economy? It might be representative only of the sector of processing trade, i.e., manufacturing activities that import parts and components, assemble into finished products, and re-export to the world market. Exports under the category of processing trade had accounted for approximately half of the annual value of Chinaees total merchandise exports from the mid-1990s until 2010, before turning to continuous decline to gradually reach $34 \%$ in 2016 . Measured as the ratio of net to gross exports, the ratio of domestic value-added of processing trade steadily increased from around $20 \%$ in the mid- 1990 s to reach the peak level of $45 \%$ by 2009 . The value-added so calculated for 2009 was equivalent to no more than $5 \%$ of China ${ }^{\text {ee }}$ GDP. Processing trade is thus no more than an enclave sector of the Chinese economy. ${ }^{30}$

The mainstay of Chinese economic development since the late 1990s has been far more than a process of labour-intensive, export-oriented industrialization. Recall the analysis of China ${ }^{\text {ee }}$ s trade performance in Section two, and the critique of the thesis of under-cutting in Section three. The rising share of machinery and transport equipment in total exports, the persistence of trade surpluses amid rapid currency appreciation, the continuous wage rise, and, most fundamentally, the fast productivity growth, all indicating that ,cheap labour ce can hardly be a significant underpinning of Chinaee export and economic growth. Sustained rapid growth in productive investment, in defiance of the broader context of financialization, is far more important.

It has been suggested elsewhere that, since the late 1990s, Chinese economic development has exhibited a tendency of converging to what can be termed the „Golden Age Model ${ }^{\text {ee }}$, i.e., the economic model that prevailed in advanced capitalist economies in the era 1950-1975. Characteristic of the model is synchronous growth in labour productivity and the wage rate, which, in turn, underpins synchronous growth in investment and consumption. It is with this tendency that China has been able to sustain its income growth, and therefore its absorption of primary commodities from the rest of the 
world on a gigantic scale. This import appetite, together with the inclination to depress export prices by the sector of the „Foxconn Modele ${ }^{\text {ee }}$, explains the spectacular trend of deterioration of China ${ }^{\text {ee }}$ terms of trade with the rest of the developing world. ${ }^{31}$

Now, consider issues of predation. In the first decade of the Twenty-first Century, there was a notable trend in the world of finance: massive increases in the official holding of reserves in foreign exchange by developing economies. Measured as a ratio to their monthly-average import values, the official holdings by developing economies increased from 5.2 months in 2000 year-end to 10.6 months in 2014 year-end. The ratio for China alone increased from 7.9 to 20.8 months. In contrast, the ratio for developed economies increased only slightly, from 2.4 to 3.2 months. ${ }^{32}$ In the face of increasing financialization of the world economy, developing economies had to accumulate reserves for protecting their currencies against speculative runs. Given the low rates of returns to the reserves, the accumulation entails paying seigniorage to the reserves currencies-issuing countries - a tributary transfer of economic surplus to the financial hegemons of the world.

The situation with China could be considered as the extreme of this outward surplus transfer. In addition to facing the general pressure of global financialization, China has had to confront conundrums arising from what Ronald McKinnon and Gunther Schnabl term „currency mismatches ${ }^{\text {ee }}{ }^{33}$ Whilst being the biggest trading economy in the world, with the biggest trade surplus, China $\mathrm{e}$ c currency is not sufficiently important in the international monetary system for financing the surplus. It thus had to accumulate reserves in the period 2000-2014. Worse, pressed by its trading partners for reducing trade surplus, it had to allow its currency to continuously appreciate after 2005, and this invited massive inflows of „hot moneye only to further increase official reserves.

Things seem to have worsened after 2008. Amid the unfolding Great Recession worldwide, predatory activities via hegemony in the international monetary system have become all the more reckless. It is reported that the series of Quantitative Easing in developed economies resulted in the flooding of „hot money ${ }^{\text {ee }}$ in developing economies, and, with leveraged effects, generated serious asset 
bubbles. ${ }^{34}$ The reverse flows after 2014, again with leveraged effects, resulted in bursting of the bubbles. These inflows and outflows of ,hot money“e, manipulated by the financial hegemons of the world, have been exceedingly harmful to developing economies. China, for one, has suffered from the associated booms and busts with its asset markets. Its loss of foreign exchange in 2015 due to capital outflows, for instance, is estimated to exceed 600 billion US dollar. ${ }^{35}$ The severe fluctuations in its stock market in 2015, and with it fluctuations in its exchange rate, were to a significant measure related to these inflows and outflows of ,hot money".

In the attempt to cope with „currency mismatches ${ }^{\text {ec }}$, after 2008, China speeded up the process of the internationalization of its currency, the Renminbi yuan, and one set of policies being taken centre on opening up the domestic financial market. Yet, these policies have proved to be problematic. The massive inflows and outflows of „hot money" have caused booms and busts in the domestic asset markets. Worse, they have also caused serious crowding-out effects on productive investment, forcing Chinese industrial firms to become increasingly speculation-oriented. The likely outcome of promoting yuan internationalization under the existing international monetary system is, at best, to financialize the Chinese economy with a hope of sharing the hegemony, i.e., to transform itself into purely a part of neoliberal globalization. The more likely outcome, however, is to fall prey to the existing financial hegemons of the world.

In summary, hitherto, China has been partly submissive to the prevailing systemic dynamics of world development, in the form of the „Foxconn Model ${ }^{\text {ee }}$ in production and falling prey to international speculative interests in finance. It has also been partly resistant to the dynamics, in the form of the domestic structural-institutional arrangements that have generated the tendency of converging to the „Golden Age Model ${ }^{\text {ee }}$. In recent years, the Chinese leadership has initiated a range of international programmes - the „Belt and Road Initiative ${ }^{e e}$ programme, the Asian Infrastructural Investment Bank, the New Development Bank, etc. - aimed at reshaping the economic landscapes of the world. One objective of the programmes is to promote yuan internationalization in a way that forces finance to serve productive activities, rather than attempting to join the existing, speculation- 
oriented financial hegemons of the world. The success or failure of this pursuit of an alternative to the prevailing systemic dynamics of world development will be of fundamental importance, not only for China itself but also for its impact on the broader developing world.

\section{Conclusions}

China "e s economic expansion over the past two decades has been of world-scale importance. This has induced enormous scholarly efforts to clarify its dynamics and ramifications. This paper seeks to contribute to the literature by means of attempting a delineation of the systemic dynamics of China, and of neoliberal globalization. The objective is to construct an appropriate conception of the systematic impact of China on world development.

Many existing studies have coalesced around the theses of „China reinforcing Southern deindustrialization" and „China under-cutting Southern labour"e, with ample supportive evidence. Yet, the theses themselves cannot be said to be sufficient for assessing the systematic impact of China on world development. They need to be contextualized, both theoretically within broader frameworks that take into account of further effects that might have been brought about by China, and empirically in terms of the overall picture of the actual process of world development.

For the thesis of „reinforcing de-industrialization“, this paper argues that it is deficient at the systematic level. The rest of the developing world has had considerable expansion in manufacturing production and export, precisely in the period that China became a world-significant player in international trade and investment. For the thesis of ,under-cutting labour", which largely hinges on the perception of a China-created ,race to the bottom “, this paper argues that it is wrong because

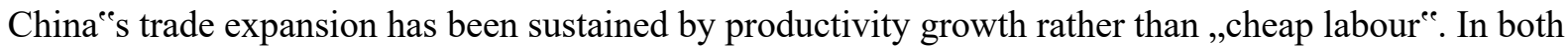
instances, the contrast in production and trade performance is instead attributed to the difference between China and the rest of the developing world in productive investment. 
Further discussion on the broader picture of world development suggests that its systemic dynamics has been dominated by a process of ,,accumulation by dispossession ${ }^{e e}$. This takes the forms of financial predation and labour absorption, leading to under-investment across the world. China $\mathrm{e}$ political economy has hitherto been mainly production-oriented in nature. This nature, by promoting productive investment both domestically and in the broader world, has served as a countervailing force against the speculation-oriented nature of the world market. 


\section{Notes:}

1. Wage data from International Labour Organization, Global Wage Report 2018/19. Other data from World Bank, World Development Indicators, accessed on 10 September 2019. Unless otherwise indicated, all the data used in this paper are from the same World Bank sources.

2. This paper dwells on the systematic impact of China on world development with respect to the economic issues of income creation and acquisition. There are further issues that are bound to embody China"s systematic impact on world development, perhaps most importantly those concerning the global climatic change - that is, the emission of greenhouse gases and the sharing of the rights (and responsibilities) of emission. These further issues are beyond the scope of the paper.

3. The term ,systemice is used in this paper to capture the essential character of the institutional arrangements and rules that govern world economic activities. This is to be distinguished from the term ,systematice, which means „system-wide ${ }^{e c}$ in scale or scope. The exposition in Section four below will concretize the notion of systemic dynamics.

4. Exchange rate data from Bank of International Settlement, Effective Exchange Rate, accessed on 11 June 2018.

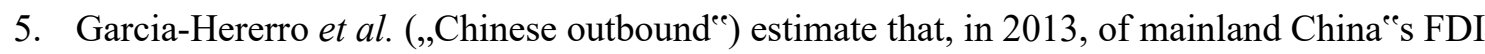
flows to Hong Kong, 40\% were round-trip back to the mainland, 30\% stayed in Hong Kong, and the remaining $30 \%$ were distributed to the rest of the world. In that year, the flows to Hong Kong accounted for $58 \%$ of China ${ }^{e s}$ total FDI flows to the world. This proportion is broadly in line with the general trend: as of 2018 year-end, Hong Kong still accounted for 56\% of the stock of mainland China ${ }^{e e}$ s outward FDI (whilst Cayman Islands and British Virgin Islands, another two „tax havens ${ }^{e e}$, combined to accounted for $20 \%$ ).

6. Data sources for the next three paragraphs are from National Bureau of Statistics of China, China Statistical Yearbook, and Ministry of Commerce of China, Report on Development of 
China's Outward Investment and Economic Cooperation and Statistical Bulletin of China's Outward Direct Investment, various issues.

7. The pattern of geographical distribution could be significantly altered by the intermediation of Hong Kong, which is included in the category of ,developing economies ${ }^{\text {ee }}$. Taking into account of the estimates in note 5, and assuming that all non-round-trip FDI flows that passed through Hong Kong ended up in the developed world (and Hong Kong itself being recategorized as a developed economy), the proportion of China"es FDI flows to developed economies could then be as high as $48 \%$ of the total in 2018 . This might be an inflation, though, as some of the non-round-trip FDI flows could end up in developing economies.

8. There is a possibility that the data of sectoral distribution of Chinaes FDI in Latin America could be distorted by the concentration of the flows to holding companies in Caribbean tax havens (British Virgin Islands and Cayman Islands), which are used as intermediate destinations.

9. A caveat concerning definitions needs to be stressed. For the thesis of „China reinforcing Southern de-industrialization ${ }^{\text {ee }}$, the relevant studies mostly focus on the displacement effect (and the primarization effect) of Chinese exports on the scale of industrial activities in the developing economies concerned. This focus deviates from the definition, traditionally used in the relevant policy discourse, of de-industrialization as a process of decreasing shares of industry in the economy. As can be seen from Table 2 below, de-industrialization in this traditional definition seems to have prevailed in the developing world irrespective of China, and China itself has actually undergone the same process of de-industrialization so defined.

10. The literature on „China reinforcing Southern de-industrialization ${ }^{e e}$ is rich. Below are some representative examples. On East Asia, see Eichengreen et al. („Impact on other Asian“), Greenaway et al. („Has China displaced“), and Hart-Landsberg and Burkett („China and Socialism"). On Sub Saharan Africa, see Buse et al. („China" s impact"), Edwards and Jenkins

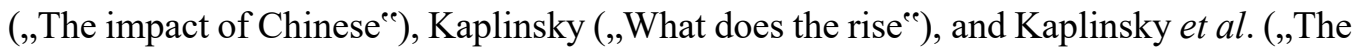


impact of China ${ }^{e e}$ and „China and Sub Saharan Africae). On Latin America, see Álvarez and Claro („David versus Goliath“), Gallagher et al. („,The dynamism of Mexican exports“), Jenkins („Measuring the competitive threat" and „Latin America and China ${ }^{\text {e) }}$, and Jenkins et al. (,The impact of China").

11. Fu et al., „The impact of Chinaee

12. See Jenkins („Latin America and China ${ }^{e \odot), ~ R o s a l e s ~ a n d ~ K u w a y a m a ~(C h i n a ~ a n d ~ L a t i n ~ A m e r i c a), ~}$ Sandrey and Edinger (,Chinaes manufacturingee), and Pigato and Tang („China and Africae ${ }^{e e}$.

13. Again, a caveat concerning definitions needs to be stressed. For the thesis of „Chinaundercutting Southern laboure, the relevant studies tend to hold the view that it entails a process of „the race to the bottome where the bottom is determined by labour condition in China. This is precisely the meaning of ,under-cuttingee. Yet, it is conceivable that developing economies could still be forced, by the competitive pressure of Chinese exports, to „cheapen " labour irrespective of the labour condition in China. The competitive pressure can still be in place with improving labour condition in China, provided that its productivity growth exceeds the improvement. This points to the importance of productive investment.

14. See Baah and Jauch („Chinese investments in Africa"), and Brautigam (The Dragon's Gift).

15. Dollar (China's Engagement with Africa) provides a survey of the issue in multiple countries.

16. See Lee („,The spectre of Global China ${ }^{e \odot}$, and Tang („Does Chinese employment ${ }^{\text {te }}$.

17. See Chan („Race to the bottom“), Foster and McChesney (The Endless Crisis), Hart-

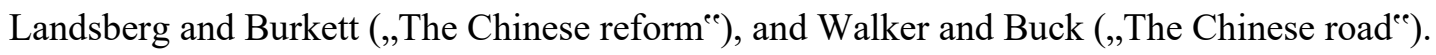

18. See Álvarez and Claro („David versus Goliath"), and Edwards and Jenkins (,The impact of Chinesee).

19. Wood and Mayer („Has China deindustrialised ${ }^{\text {‘e }}$.

20. di Giovanni et al., „,The global welfare impacte.

21. Wolf, „China and latecomer" and „Industrialization in times" of the combined impact of the various China-generated effects, there are diverse findings 
from different studies. Yoshimichi Murakami and René Hernández („,The impact of China ${ }^{e \bullet}$, in a balance-of-payments-constrained growth analysis, find that the China impact on three Latin American economies is positive but rather modest. In a separate study of China"es impact on a sample of 62 developing economies, Teng and Lo („Determinants of developing ${ }^{\text {ee }}$ find that the balance-of-payment effect is indeed insignificant. Yet, they also find that the terms of trade effect is significant and strong in raising the productive investment and export sophistication of the developing economies concerned.

22. Poon, „China ${ }^{e e}$ development

23. Rodrik „Premature de-industrialization“, and Felipe and Mehta,De-industrialization?" .

24. See Lazonick, Sustainable Prosperity, and Wade, „Choking the South“e

25. Harvey, A Brief History.

26. Wade and Veneroso, „The Asian crisis ${ }^{\mathrm{e}}$.

27. IMF, World Economic Outlook, April 2007.

28. Data from UNCTADsta, accessed 8 May 2016.

29. See Foster and McChesney, The Endless Crisis, Hart-Landsberg and Burkett, „TheChinese reformee, and Smith, Imperialism.

30. For a detailed analysis of the scale and character of China ${ }^{a e s}$ processing trade, and the dualistic structure of the Chinese economy, see Lo, „China and world

31. The synchronous, rapid growth of the wage rate and labour productivity in the period 20002016 has been reported in Section three. In the same period, there was also synchronous growth in consumption and investment of unprecedentedly fast speed: the average annual growth rate, in real terms, was $9.8 \%$ for consumption and $12.7 \%$ for investment. These synchronous growths were underpinned by an institutional framework that resembles the „Golden Age Model"e. For further details, see Lo, „China confronts"e.

32. Data from International Monetary Fund (IMF), COFER, accessed $17^{\text {th }}$ May 2018, and World Economic Outlook, various issues. 
33. McKinnon and Gunther Schnabl, „China"s financial"e and „China“es exchange rate

34. Palma, „Why corporations ${ }^{e e}$.

35. Institute of International Finance, „Capital flows to emerging market”, 19 January 2016, https://images.magnetmail.net/images/clients/IIF_2/attach/CF_0116_Press(3).pdf

\section{Bibliography}

Álvarez, R., and S. Claro, 2009. „David versus Goliath: the impact of Chinese competition on developing countriese, World Development, 37 (3): 560-571.

Baah, A.Y., and H. Jauch, 2009. „Chinese investments in Africae, in. A.Y. Baah and H. Jauch (eds.) Chinese Investments in Africa: A Labour Perspective, Windhoek, Namibia, African Labour Research Network.

Brautigam, D. 2009. The Dragon's Gift: The Real Story of China in Africa, Oxford, Oxford University Press.

Buse, M., C. Erdogan, and H. Mühlen. 2016. „China's impact on Africa: the role of trade, FDI and aid"e, Kyklos, 69 (2), 228-262.

Chan, A. 2003. „A "race to the bottom”: globalisation and China "s labour standards", China Perspectives, no.46, http://chinaperspectives.revues.org/259

di Giovanni, J., A.A. Levchenko, and J. Zhang. 2014. „The global welfare impact of China: trade integration and technological change ${ }^{e e}$, American Economic Journal: Macroeconomics, 6 (3): 153-183.

Dollar, D. 2016. China's Engagement with Africa: From Natural Resources to Human Resources, Washington, D.C.: The Brookings Institution. 
Edwards, L., and R. Jenkins. 2015. „The impact of Chinese import penetration on the South African manufacturing sectore, Journal of Development Studies, 51 (4): 447-463.

Eichengreen, B., Y. Rhee, and H. Tong 2004. „The impact of China on the exports of other Asian countries"e, NBER Working Paper 10768.

Felipe, J. and A. Mehta. 2016. „De-industrialization? A global perspective ${ }^{e e}$, Economic Letters, 149: $148-151$.

Foster, J.B. and R. McChesney 2012. The Endless Crisis: How Monopoly Finance Capital Produces Stagnation and Upheaval from the USA to China, New York: Monthly Review Press.

Fu, X., R. Kaplinsky and J. Zhang 2012. „The impact of China on low and middle income countries: export prices in industrial-country marketse, World Development, 40 (8): 1483-1496.

Gallagher, K., J.C. Moreno-Brid, and R. Porzecanski 2008. „The dynamism of Mexican exports: lost in (Chinese) translation?"e, World Development, 36 (8): 1365-1380.

Garcia-Hererro, A., L. Xia, and C. Casanova 2015. „Chinese outbound foreign direct investment: how much goes where after round-tripping and off-shoringe', Working Paper no.15/17, BBVA.

Greenaway, D., A. Mahabir, and C. Milner. 2010. „Has China displaced other Asian countries exports?e, in D. Greenaway, C. Milner, and S. Yao (eds.) China and the World Economy, Basingstoke, Palgrave Macmillan.

Hart-Landsberg M. and P. Burkett 2005. China and Socialism: Market Reforms and Class Struggle, New York: Monthly Review Press.

Hart-Landsberg M. and P. Burkett 2011. „The Chinese reform experience: a critical assessment Review of Radical Political Economics, 43 (1): 56-76.

Harvey, D. 2005. A Brief History of Neoliberalism, Oxford, Oxford University Press. 
Jenkins, R. 2008. „Measuring the competitive threat from China for other Southern exporters"e, The World Economy, 31 (10): 1351-1366.

Jenkins, R. 2012. „Latin America and China: a new dependency?, Third World Quarterly, 33 (7): $1337-1358$.

Jenkins, R., E.D. Peters, and M.M. Moreira 2008. „The impact of China on Latin America and the Caribbean"e, World Development, 36 (2): 235-253.

Kaplinsky R. 2008. „What does the rise of China do for industrialisation in Sub Saharan Africa?", Review of African Political Economy, 35 (115): 7-22.

Kaplinsky, R., D. McCormick, and M. Morris 2007. „The impact of China on Sub Saharan Africaee, IDS Working Paper no.291, http://www.ids.ac.uk/files/Wp291.pdf

Kaplinsky, R., D. McCormick, and M. Morris 2010. „China and Sub Saharan Africa: impacts and challenges of a growing relationship"e, in V. Padayachee ed., The Political Economy of Africa, London: Routledge.

Lazonick, W. 2009. Sustainable Prosperity in the New Economy?, Kalamazoo, Michigan: W.E. Upjohn Institute for Employment Research.

Lee, C.-K. 2014. „The spectre of Global China“e, New Left Review, no.30: 28-65.

Lo, D. 2013. „China and world development - beyond the crisise, in N. Yokogawa, J. Ghosh and R. Rowthorn (eds.) Industrialization in China and India: Their Impacts on the World Economy, London, Routledge

Lo, D. 2016. „China confronts the Great Recession: "rebalancing” neoliberalism, or else?"e, in P. Arestis and M. Sawyer (eds.) Emerging Economies During and After the Great Recession, (International Papers in Political Economy 2016 ), Basingstoke, Palgrave Macmillan. 
McKinnon, R. and G. Schnabl 2009. „China“es financial conundrum and global imbalances ${ }^{e e}$, BIS Working Papers no.277, Bank of International Settlement, http://www.bis.org/publ/work277.pdf

McKinnon, R. and G. Schnabl 2014. „China"e exchange rate and financial repression: the conflicted emergence of the RMB as an international currencye, China \& World Economy, 22 (3): 1-34.

Murakami, Y., and R. Hernández 2018. „The impact of China on economic growth: evidence for Brazil, Chile and Peru', Journal of Post Keynesian Economics, 41 (3): 430-454.

Palma, J.G. 2015. „Why corporations in developing countries are likely to be even more susceptible to the vicissitudes of international finance than their counterparts in the developed world: a tribute to Ajit Singh"e, Cambridge Working Papers in Economics, CWPE 1539, http://www.econ.cam.ac.uk/research/repec/cam/pdf/cwpe1539.pdf

Poon, D. 2015. „China"es development trajectory: a strategic opening for industrial policy in the South“, UNCTAD Discussion Papers no.218.

Rodrik, D. 2015. „Premature de-industrialization“, IAS Economic Working Papers no.107.

Rosales O., and M. Kuwayama 2012. China and Latin America and the Caribbean: Building a Strategic Economic and Trade Relationship, Santiago, ECLAC.

Sandrey, R., and H. Edinger 2011. „China"es manufacturing and industrialization in Africa ${ }^{e e}$, African Development Bank, working paper no.128, http://www.afdb.org/fileadmin/uploads/afdb/Documents/Publications/Working\%20128.pdf

Smith, J. 2016. Imperialism in the Twenty-First Century: Globalization, Super-Exploitation, and Capitalism's Final Crisis, New York: Monthly Review Press.

Tang, X. 2016. „Does Chinese employment benefit Africans? Investigating Chinese enterprises and their operations in Africa ${ }^{e e}$, African Studies Quarterly, 16 (3-4): 107-128. 
Teng, Y., and D. Lo 2019. „Determinants of developing countriese export upgrading: the role of China and productive investmente, SOAS University of London, Economic Department Working Paper no.227.

Wade, R.H. 2006. „Choking the South“, New Left Review, 38: 115-127.

Wade, R.H. and F. Veneroso 1998. „The Asian crisis: the high debt model versus the Wall StreetTreasury-IMF Complex", New Left Review, 228: 3-23.

Walker, R. and D. Buck 2007. „The Chinese road: cities in the transition to capitalismee, New Left Review, no.46: 39-66.

Wolf, C. 2016. „China and latecomer industrialization processes in Sub-Saharan Africa: a case of combined and uneven developmentec. World Review of Political Economy, 7 (2): 249-84.

Wolf, C. 2017. „Industrialization in times of China: domestic-market formation in Angola ${ }^{e c}$. African Affairs, 116 (464): 435-61.

Wood, A. and J. Meyer 2011. „Has China deindustrialised other developing countries? World Economics, 147 (2): 325-350. 
Table 1. Composition of Exports and Imports (US\$ billion)

\begin{tabular}{|c|c|c|c|c|c|}
\hline & 1980 & 1990 & 2000 & 2018 & $2018 / 1980$ \\
\hline \multicolumn{6}{|l|}{ Exports } \\
\hline Total merchandise & 18 & 62 & 249 & 2487 & 137 \\
\hline Manufactures & 9 & 46 & 224 & 2352 & 261 \\
\hline Machinery and transport equipment & 1 & 6 & 83 & 1208 & 1433 \\
\hline \multicolumn{6}{|l|}{ Imports } \\
\hline Total merchandise & 20 & 53 & 225 & 2135 & 107 \\
\hline Manufactures & 13 & 44 & 178 & 1434 & 110 \\
\hline Machinery and transport equipment & 5 & 17 & 92 & 840 & 164 \\
\hline \multicolumn{6}{|l|}{ Exports/Imports ratio } \\
\hline Total merchandise & 0.91 & 1.16 & 1.11 & 1.16 & \\
\hline Manufactures & 0.69 & 1.06 & 1.25 & 1.64 & \\
\hline Machinery and transport equipment & 0.16 & 0.33 & 0.90 & 1.44 & \\
\hline
\end{tabular}

Sources: China Statistical Yearbook, various issues. 
Figure 1. China's Merchandise Trade (current US\$ million)

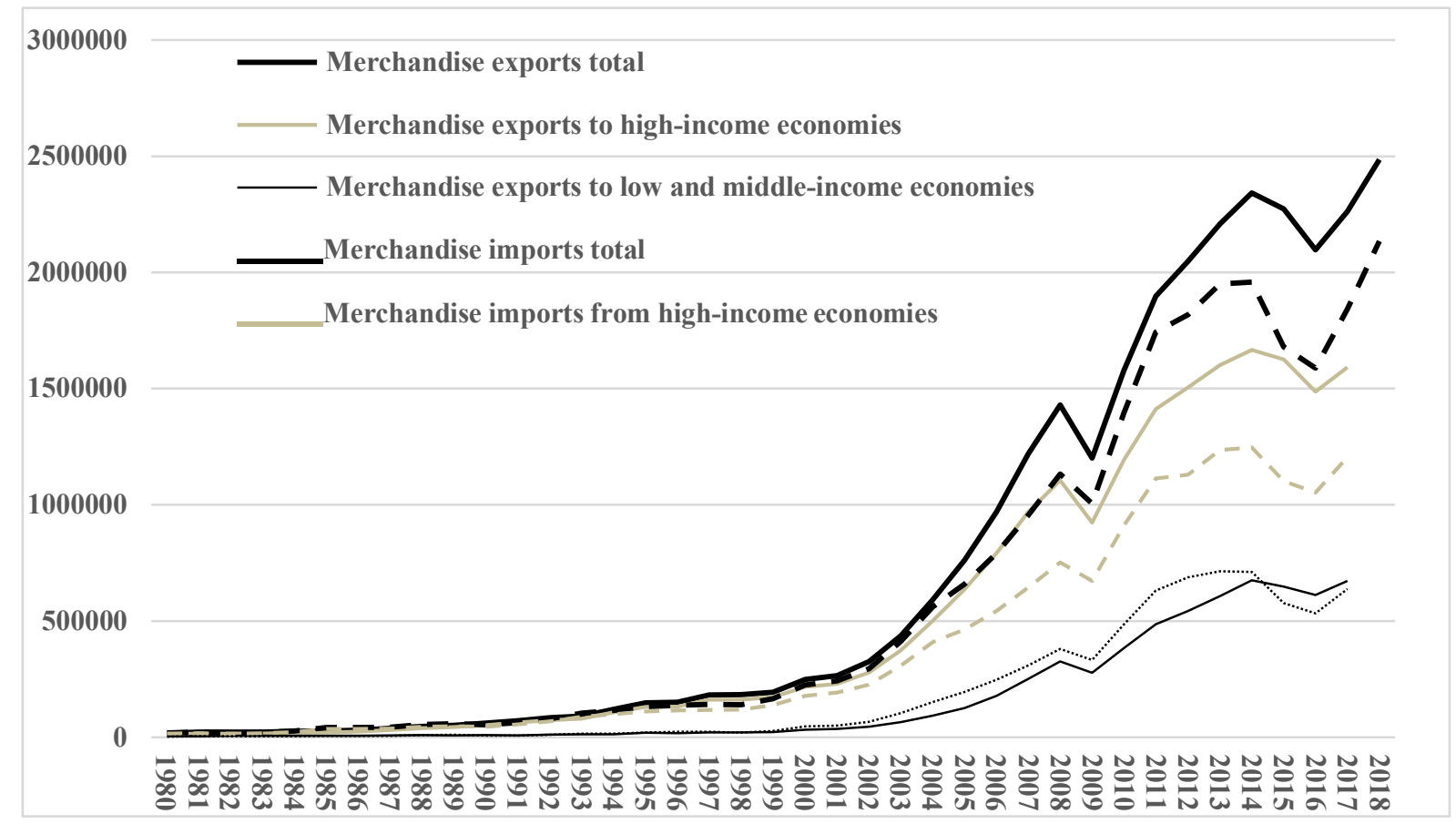

Sources: World Bank World Development Indicators, accessed $2^{\text {nd }}$ December 2019. 
Figure 2. Net Barter Terms of Trade $(1990=100)$

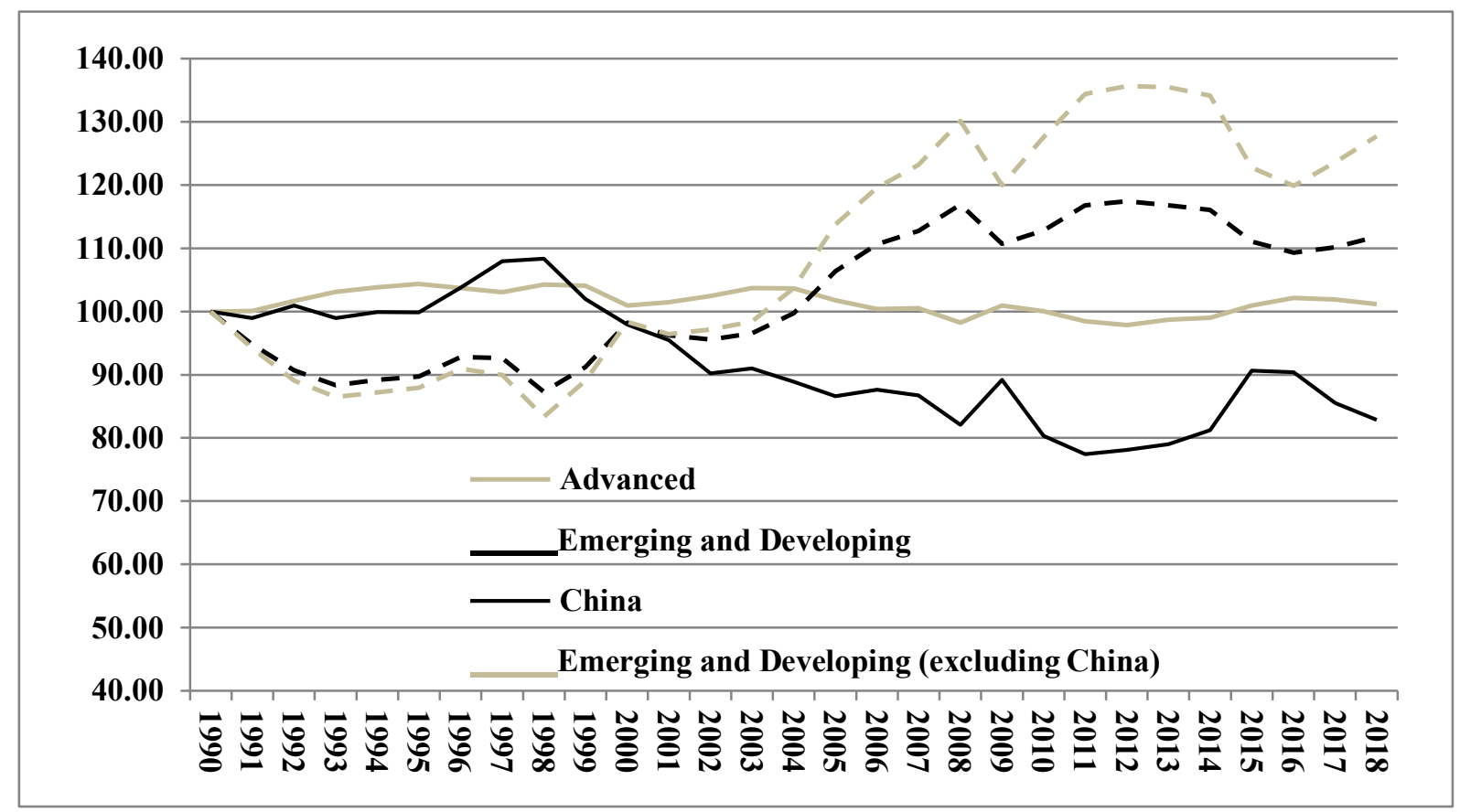

Sources: IMF World Economic Outlook, various issues; and World Bank World Development Indicators, accessed $2^{\text {nd }}$ December 2019.

Note: Data of "Emerging and Developing Economies (Excluding China)" are estimates, assuming that they are weighted averages of the terms of trade of China and the rest of the developing economies and using data of their respective total merchandise trades as the weightings. 
Figure 3. China's FDI (Flows, US\$ million)

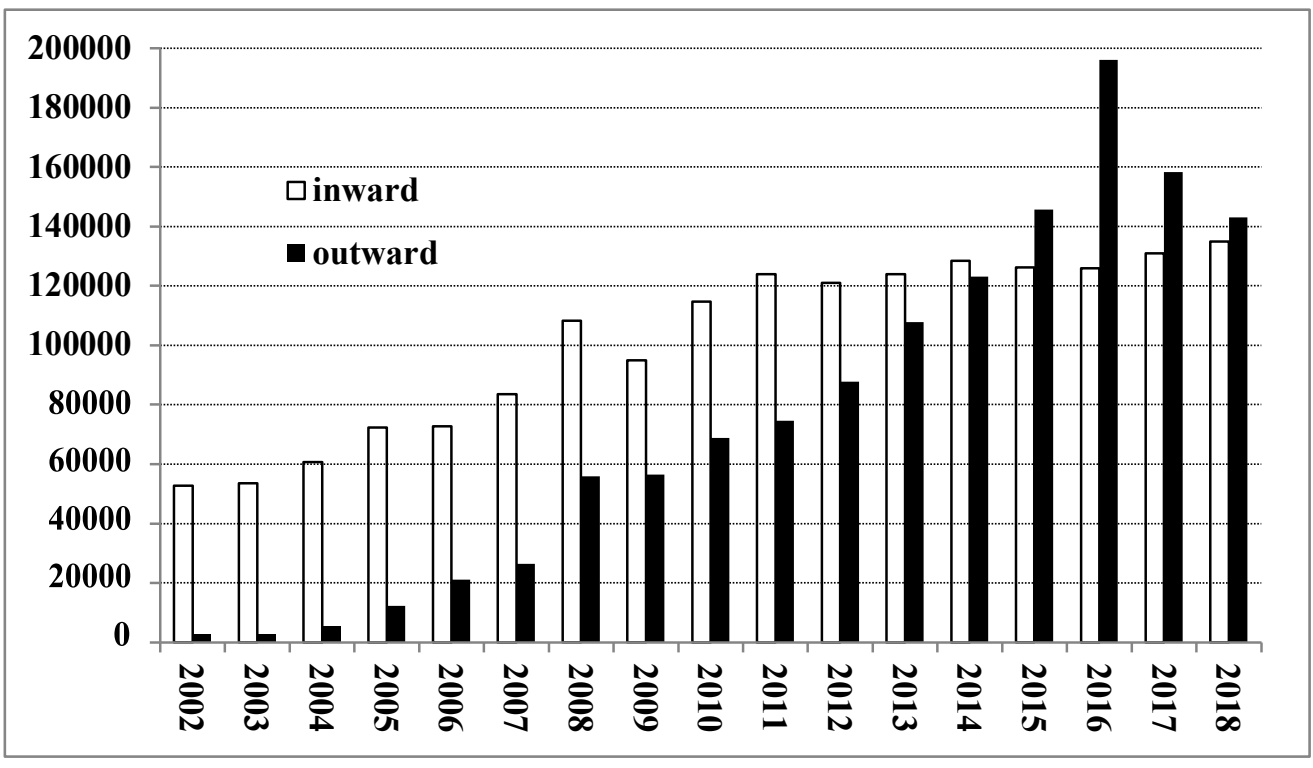

Sources: China Statistical Yearbook and Report on Development of China's Outward Investment and Economic Cooperation, various issues. 
Figure 4. World Shares of Manufacturing Exports

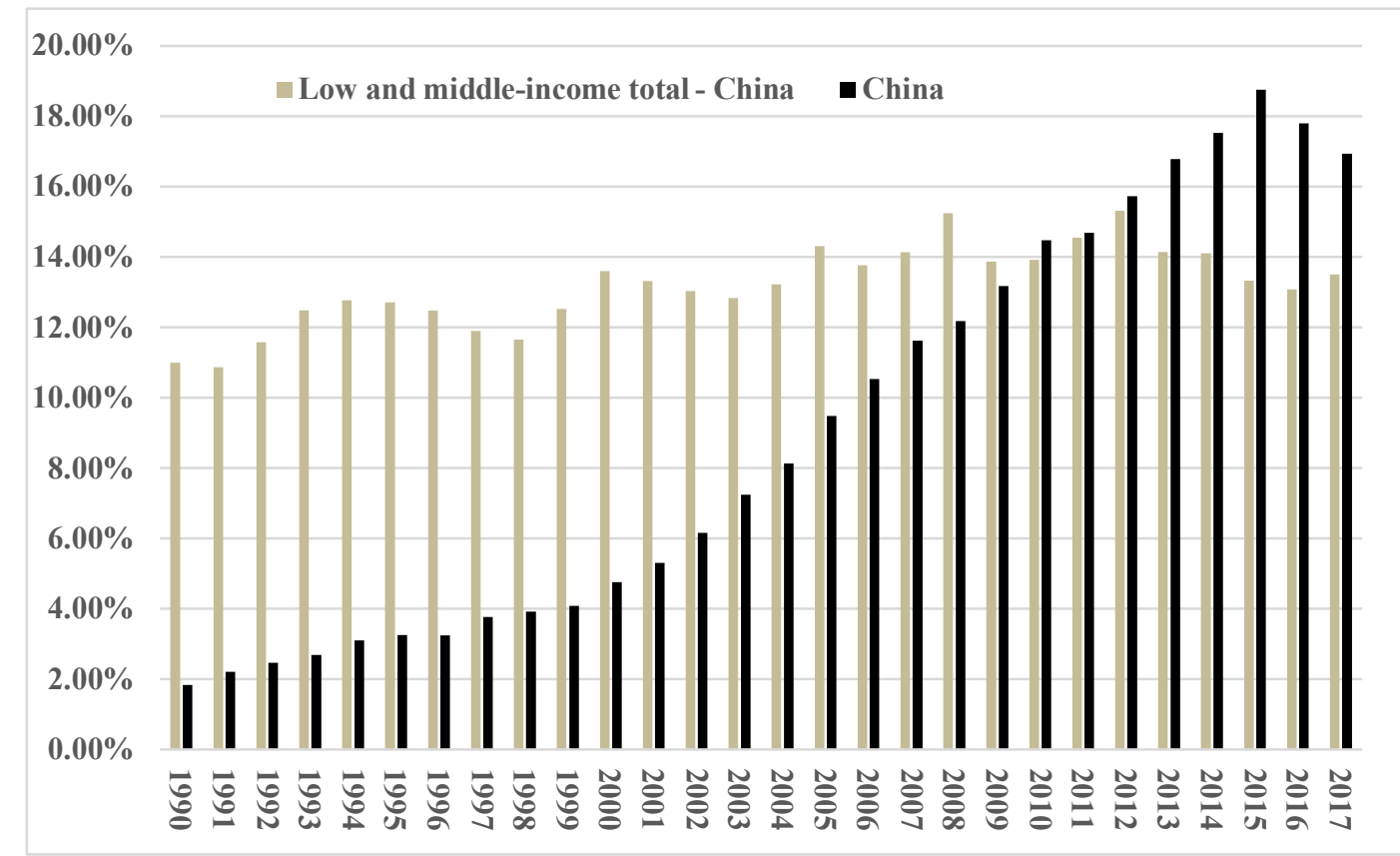

Sources: World Bank World Development Indicators, accessed 10 ${ }^{\text {th }}$ September 2019. 
Figure 5. World Shares of Manufacturing Value-added

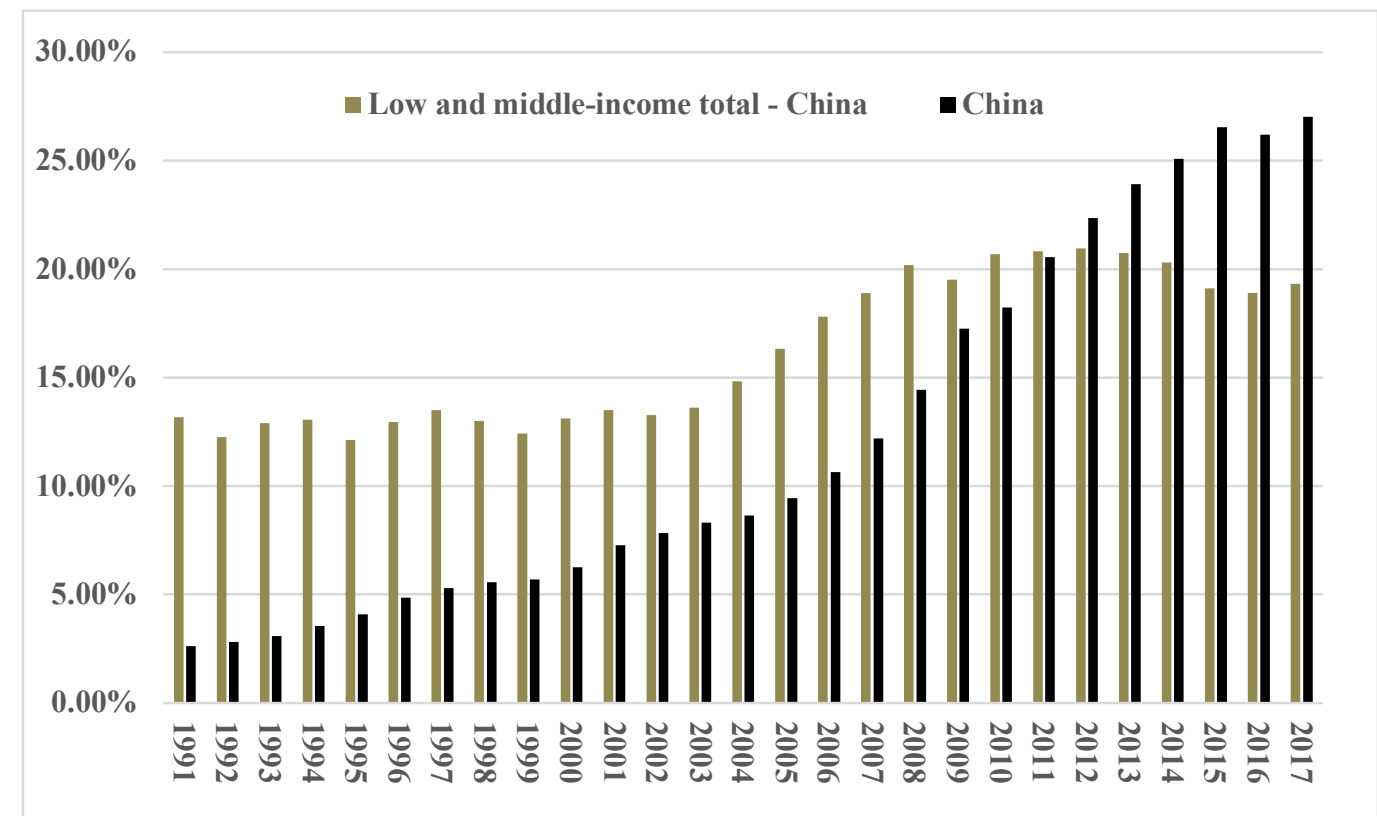

Sources: World Bank World Development Indicators, accessed 10 ${ }^{\text {th }}$ September 2019. 
Table 2. Gross Capital Formation and Manufacturing Value-added (average \% of GDP)

\begin{tabular}{|l|r|r|r|}
\hline & $1970-1979$ & $1980-1999$ & $2000-2017$ \\
\hline Gross capital formation (\% of GDP) & & & \\
\hline China & $34.0 \%$ & $37.2 \%$ & $43.1 \%$ \\
\hline Low \& middle income - China & $26.6 \%$ & $24.8 \%$ & $24.7 \%$ \\
\hline Manufacturing value added (\% of GDP) & $36.8 \%$ & $34.2 \%$ & $31.3 \%$ \\
\hline China & $17.9 \%$ & $18.0 \%$ & $15.6 \%$ \\
\hline Low \& middle income - China & & & \\
\hline
\end{tabular}

Sources: World Bank World Development Indicators, accessed 23 ${ }^{\text {rd }}$ May 2018 and $13^{\text {th }}$ January 2019. 
Figure 6. Indices of Per-Worker Real GDP and Real Wage Rates $(2000=100)$

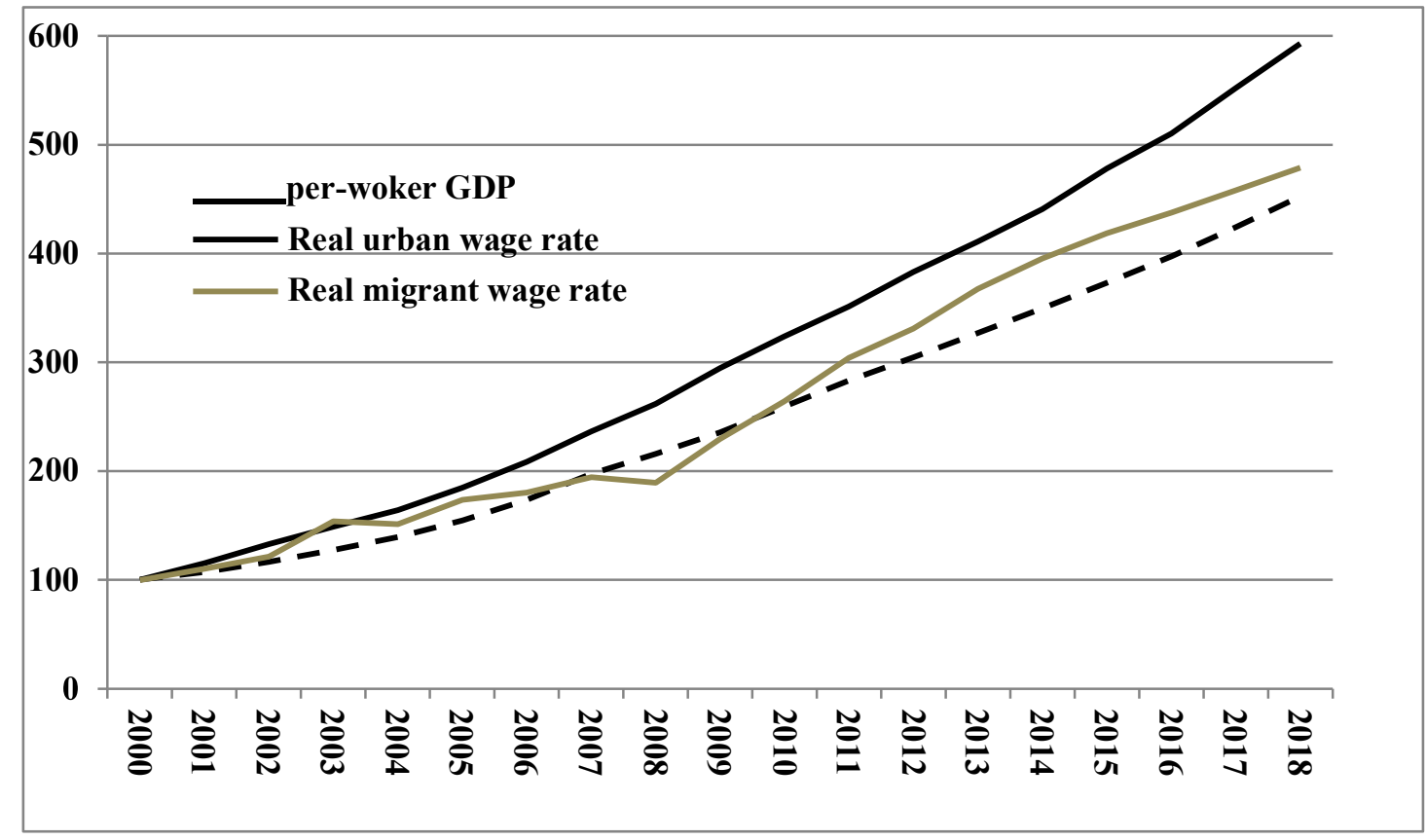

Sources: Per-worker real GDP and urban wage rate data from China Statistical Yearbook, various issues; wage rate data for migrant workers from Report on Monitoring and Surveying Migrant Workers, various issues, and Lu Feng (2012) "Wage rate trends of China"s migrant workers, 1979-2010"e, Zhongguo Shehui Kexue (Social Sciences in China), 2012, no.7: 47-67. 